\title{
Development of a Relative Vulnerability Index (RVI) for Estimation of Building Vulnerability towards Tsunami Hazard
}

\author{
Leli Honesti $^{1 *}$, Muhd Zaimi Abd Majid ${ }^{2}$, Nazwar Djali ${ }^{3}$, Meli Muchlian ${ }^{1}$, Syofyan $Z^{1}$ \\ ${ }^{1}$ Department of Civil Enginering, Faculty of Civil Enginering and Design, Institut Teknologi Padang, Indonesia \\ ${ }^{2}$ Department of Structure and Material, Faculty of Civil Engineering, Universiti Teknologi Malaysia, Malaysia \\ ${ }^{3}$ Department of Civil Enginering, Faculty of Civil Enginering and Design, Bung Hatta University, Indonesia
}

\begin{abstract}
Tsunami hazard is an adverse event, which causes damage to properties and loss of life. The study on the effects of tsunami hazard on building vulnerability can help establish and improve the resilience of the building. The problem in assessing the building vulnerability towards tsunami hazard is significant whereby available models for assessing the risk are not applicable for buildings in Padang, Indonesia. The study developed a new Relative Vulnerability Index (RVI) model to estimate building vulnerability for assessment the risk. Literature review was carried out with regards to model development. The model was grouped in two categories of vulnerability, namely the Water Inundation (WI) and the Building Vulnerability (BV). The water inundation comprises tsunami inundation factor. Then, the building bulnerability consists of both internal and external factors. Contribution of each factor is $1 / 3$ or $33.33 \%$ of the overall weighting of the new $\mathrm{RVI}$ scores. The new RVI model has applied a formula of $1 / 3$ water (tsunami) inundation factor + $1 / 3$ internal factor $+1 / 3$ external factor. The total value of all weights put together should be equal to 100 . To use the model, it is necessary to investigate two internal and external factors based on the characteristics of a building and specific geographichal feature of an area. In conclusion, this study has successfully developed a new RVI model for building vulnerability towards tsunamis. In comparison to other approaches, the model offers an adaptable methodology for the characteristics of the buildings and spesific geographical features of the area.
\end{abstract}

\section{Introduction}

Indonesia is a big country which is highly exposed to tsunami risk. In the last two centuries, there were four major earthquakes that occurred in the Sumatra subduction zone, which include in 1833 with a magnitude of 8.8 to 9.2 Richter scale [1](McCloskey et al., 2008), and in 1797 with a magnitude of 8.5 to 8.7 Richter scale [2](McCloskey et al., 2010). On the 26th of December, 2004 with a magnitude of 9.0 to 9.3 Richter scale, the region of Aceh was shaken by a tsunami. The tsunami ruptured major fault zones ocean - Australia along the $1300 \mathrm{~km}$ [3](Suppasri et al., 2010). The impacts of this tsunami have caused serious damaged on infrastructure and buildings along the coast with 300,000 reported casualties. On the 28th of March, 2005, the Sumatran megathrust subduction zone collapsed in the magnitude of 8.7 Richter scale earthquake in Nias, where more than 200 buildings were destroyed [4](Briggs et al., 2006).

Hazard assessment, vulnerability and risk contribute substantially to identify and establish tsunami risk zones for buildings along coastal areas. Tsunami simulation can be considered as water vulnerability [5](Honesti et al., 2014). Mardiatno (2008) classified the height of run up into three categories; namely low, medium and high levels and classified tsunami inundation risk into five categories; namely very low $1(>0-0.25 \mathrm{~m})$, low 2 $(>0.25-0.5 \mathrm{~m})$, moderate $3(>0.5-1 \mathrm{~m})$, high $4(>1-$ $2 \mathrm{~m})$ and very high $5(>2 \mathrm{~m})$ [6]. Muchlian and Honesti (2017) has been modelled tsunami simulations from Pagai and Sipora block sources in Air Tawar subdistrict, Padang. The tsunami wave height from the Pagai block is greater than the tsunami wave from the Sipora block. The inundation area from Pagai source is approximately 47 nested grids, and more than two-thirds of area are safe from tsunami, while the inundation area from Sipora source is approximately 19 nested grids and more than three quarters of area are safe from tsunami [7].

The problem in assessing the building vulnerability towards tsunami hazard arises as previous models for assessing the risk are not suitable to be applied in the area. Example, many buildings in Ulak Karang subdistrict, Padang, especially along the river, are made of traditional brick [8](Honesti et al., 2015). This is mainly due to the fact that there are uncertainties in the models for the building as well as the physical area characteristics of West Sumatra, Indonesia.

In the PTVA-3 model, the factors of vulnerability consist of structural vulnerability and water vulnerability. The structural vulnerability is determined by building vulnerability factors (BV) and protection factors (Prot). The building vulnerability factors (BV)

\footnotetext{
*Corresponding author: leli.honesti@itp.ac.id
} 
include: 1) number of stories; 2) building material; 3) ground floor; 4) foundation; 5) shape and orientation of building; 6) movable object as well as 7) preservation condition. The protection factors on the other hand include: 1) building row; 2) natural barrier; 3) sea wall height and shape; as well as 4) brick wall around building. The formula of the PTVA-3 model is as follow:

$$
\mathrm{RVI}=(2 / 3) \times(\text { "SV_1_5") }+(1 / 3) \times(\text { (WV_1_5") }
$$

Where "SV_1 5" is the structural vulnerability and "WV 1 5" is water vulnerability. "SV" is the standarized score for the structural vulnerability (Dall' Osso et al., 2009) [9].

The problem in complex and one of challenges faced is in the calculation of the RVI model for assessing the building vulnerability, particularly within the coastal region of Indonesia. For solution of this problem, it is important to develop the RVI model for the building vulnerability to tsunami hazard. The model especially for areas of Indonesia and the same characteristic areas. The main purpose of this research is to develop a new model to assess building vulnerability caused by tsunamis. The study developed a model in the form of a new Relative Vulnerability Index (RVI) model.

\section{Method}

This study focuses on establishing building vulnerability model, particularly for areas in Indonesia as well as those areas with the same characteristics. Here, a new RVI model was developed according to the adoption of some model about building vulnerability. The model is more accurate and more adaptable towards the variation of tsunami inundation factor and building vulnerability factors. The building vulnerability assessment was undertaken through a detailed survey in the fields. Then, the new RVI score for each inundated building was calculated using the new RVI model developed. In this case, a building vulnerability is influenced from the conditions inside of the building, known as the internal factors, and from the conditions outside of the building, with the exception of tsunami inundation, known as the external factors. The internal and external factors were established by analyzing the factors influencing building vulnerability towards tsunami inundation.

The concept of two group factors offers a useful framework for understanding the causes and effects of building vulnerability. In this context the two groups of factors indicating the levels of vulnerability can be identified on the basis of a function. The factors were developed from the RVI-3 model as well as a number of literatures by experts in the field. For example, a geophysics expert stated that existence of barrier islands, distance from the river, gap between buildings and distance from the shoreline affect building vulnerability towards the worst effects of a tsunami.

\section{Results and Discussion}

The building vulnerability to tsunami hazard is generally determined by internal and external factors of a building. These factors in this study are based on the tabulation data by finding the factors most often used by researchers in previous studies. Hajar (2006); Jelínek et al. (2009); Dall'Osso et al. (2009(a),(b)); Sumaryono (2010); Atillah et al. (2011); Barros et al. (2015) and Sivakumar and Sivagamasundari (2015) have taken the factors associated with building vulnerability [9-16].

Through this study, the internal and external building vulnerability factors have been established. There are construction material; 2) number of stories; 3) foundations; 4) preservation condition; 5) building age; 6) ground floor hydrodynamics; 7) shape and orientation of the building as internal factors and 1) movable objects; 2) building row; 3 ) height of concrete fence; 4) natural barrier; 5) the presence of a seawall; 6) distance from the shoreline; 7) distance from the river; 8) obstacle islands and 9) gap between buildings as external factors. Then, compared to the building vulnerability in other researchers, every researcher used the factors that are different compared with the others. Here, with the result that the writers combined several factors by selecting the factors that contribute greatly to the building vulnerability due to tsunami hazard. Based on the result of tabulation and the selection of internal and external factors in this research, there are some differences of factors used by every researcher in the previous researches. This is due to the fact that many factors used have significant influence of these factors on the determination of building vulnerability, but several factors did not chose because the factors do not influence significantly to the building vulnerability.

This study discusses on the process of developing an RVI model for building vulnerability developed. In developing the new RVI model, it was found that in some studies the RVI is based on vulnerability level. In PTVA-3, the RVI scores for every building were determined using a weighted attribute. The new model was developed to estimate the vulnerability pattern within predicted factors which is based on a subjective procedure that relies heavily on the expert judgement of the authors developed.

The new RVI score model was developed to provide the first order assessments of building vulnerability to tsunami hazard. The output of this model is "a New Relative Vulnerability Index" (new RVI) model for every building. In this model, the new RVI model was grouped in two categories of vulnerability, namely the Water Inundation (WI) and the Building Vulnerability (BV). The Building Vulnerability (BV) consists of both the internal and the external factors.

Reinaldi (2002) have used two scenarios to assess building vulnerability affected by an earthquake in Semarang. Here, the classification of vulnerability is presented in an RVI map of building vulnerability towards earthquake hazard. Furthermore, building vulnerability is a combination of social, disaster and physical building factors [17]. Based on the simplest model in pair wise comparison matrix of Syabri (1997) 
[18], the assessment scenarios of building vulnerability can be written in the following forms (2 and 3 ) in scenario 1 and 2 .

$$
\begin{aligned}
& \mathrm{VL}=33.33 \% \mathrm{TDF}+33.33 \% \mathrm{TSF}+33.33 \% \mathrm{TPF} \\
& \mathrm{VL}=60 \% \mathrm{TDF}+20 \% \mathrm{TSF}+20 \% \mathrm{TPF}
\end{aligned}
$$

where, VL is vulnerability level, the TDF and the TSF are the total disaster factors and the total social factors respectively. Then, the TPF is the total physical factors. These two scenarios are usually used by alchemists (Syabri, 1997). Using the pair wise comparison matrix, the levels of vulnerability can be classified into four categories: Very Low $(\mathrm{V}<1.50)$; Low $(1.50 \leq \mathrm{V} \leq 2.00)$; Medium $(2.00<\mathrm{V} \leq 2.5)$; High $(2.50<\mathrm{V} \leq 3.00)$ and Very High $(\mathrm{V}>3.00)$.

Afatia et al. (2012) have analysed the risk of a pyroclastic flow of the Semeru volcano by using the pair wise comparison matrix. The pair wise comparison matrix is a tool to rank a set of decision-making criteria and rate the criteria on a relative scale of importance. Making decisions requires comparing alternatives with respect to a particular set of criteria. If there are more than two criteria, determining which criteria is more important can it self be a serious problem. One would like to be able to rank the criteria in order of importance, and to assign to the criteria some relative ranking indicating the degree of importance of each criterion with respect to the other criteria. Every criterion is ranked based on rising interest rates, then the value of each weight is multiplied to get the weighting of each criteria [19].

The ranking of hazard, vulnerability and capacity are of the same importance if a pair wise comparison matrix for decision making of a risk analysis for scenario 1 . The pair comparison of scenario 1 is presented in Table 1 . Here, the weight of each criterion is 0.333 , with the total of all the weights must be $100 \%$. Table 2 (scenario 2) demonstrates that the pair wise comparison matrix of hazard criteria is of utmost importance. Having said that, the vulnerability is five times more important than the capacity. Thus, the last criteria introduced here is the capacity (most unimportant).

Based on the scenario 1, the new RVI can be determined as follows:

$(\mathrm{RVI})=(1 / 3) \times(\mathrm{WI})+(1 / 3) \times(\mathrm{IF})+(1 / 3) \times(\mathrm{EF})$ where: WI is water inundation and this relation gives as a result a value of WI ranging between 0 to 100 . IF is the internal factor for building vulnerability. The minimum total weight is 0 and maximum total weight is 100 . EF is the external factor for building vulnerability and the maximum total weight is also 100 .

\section{Conclusion}

There are three main factors that need to be considered in calculating building vulnerability to tsunami hazard in the study area, namely the tsunami inundation factor, the internal, and the external vulnerability factors. In the context of this RVI, it can be determined in equation (4).
A new RVI model was developed according to adoption from some model about building vulnerability. The model is more adaptable towards the variation of tsunami inundation factor and building vulnerability factors. The building vulnerability assessment is undertaken through a detailed survey in the fields. Findings from this study have established the new RVI model based on several factors including water inundation factor, internal and external factors for assessing building vulnerability towards tsunami hazard based on the building and coastal characteristics.

\section{References}

1. J. McCloskey, A. Antonioli, A. Piatanesi, K. Sieh, S. Steacy, S. Nalbant, M. Cocco, C. Giunchi, J.D. Huang, and P. Dunlop, Tsunami threat in the Indian Ocean from a future megathrust earthquake west of Sumatra. Earth and Planetary Science Letters. 265 (1-2). 61-8, (2008)

2. J. McCloskey, D. Lange, F. Tilmann, S.S. Nalbant, A.F. Bell, D.H. Natawidjaja, and A. Rietbrock, The September 2009 Padang Earthquake. Nature Geoscience. 3. 70-71. (2010)

3. A. Suppasri, F. Imamura, and S. Koshimura, Effect of the rupture velocity of fault motion, ocean current and initial sea level on the transoceanic propagation of tsunami. Coastal Engineering Journal. 52(2). 107-132, (2010)

4. R.W. Briggs, K. Sieh, A.J. Meltzner, D.H. Natawidjaja, J. Galetzka, B. Suwargadi, Y. Hsu, M. Simons, N. Hananto, I. Suprihanto, D. Prayudi, J.P. Avouac, L. Prawirodirdjo, and Y. Bock, Deformation and slip along the Sunda megathrust in the great 2005 Nias-Simeulue earthquake. Science. 311(5769). 1897-1901, (2006)

5. L. Honesti, M.Z.A. Majid, M. Muchlian, and N. Djali., Assesing Building Vulnerability to Tsunami Hazard in Padang. Jurnal Teknologi (Sciences \& Engineering). 69 (6), 5-9, (2014)

6. D. Mardinatno, Tsunami Risk Assessment Using Scenario-Based Approach, Geomorphological Analysis and Geographic Information System: A Case Study in South Coastal Areas of Java IslandIndonesia. (University of Innsbruck, Germany, 2008)

7. M. Muchlian, and L. Honesti, Pemodelan Numerik Gelombang Tsunami untuk Menentukan Luas Area Inundasi (Studi Kasus Daerah Air Tawar Padang). in Prosiding Seminar Nasional Fisika Universitas Andalas (SNFUA). Padang: Physics Department: 95-102, (2017)

8. L. Honesti, M.Z.A. Majid, N. Djali, and M. Muchlian, Modeling the Potential Risk of Building Vulnerability toward Tsunami Hazard in Ulak Karang and Pasir Jambak Sub-District, Padang. Jurnal Teknologi (Sciences \& Engineering). 72(4). 41-47, (2015)

9. F. Dall'osso, M. Gonella, G. Gabbianelli, G, Withycombe, and D. Dominey-Howes, Assessing the vulnerability of buildings to tsunami in Sydney. 
Natural Hazards Earth System Sciences. 9. 20152026, (2009)

10. F. Dall'Osso, M. Gonella, G. Gabbianelli, G. Withycombe, and D. Dominey-Howes, A revised (PTVA) model for assessing the vulnerability of buildings to tsunami damage'. Natural Hazards Earth System Sciences. 9. 1557-1565, (2009)

11. M. Hajar, Pemetaan Tingkat Kerawanan Bencana Tsunami Menggunakan Data Pengindraan Jauh dan Sistem Informasi Geografi (SIG) Studi Kasus: Kota Padang. (Bogor: Marine Science and Technology Department, Bogor Agricultural University, 2006)

12. R. Jelinek, S. Eckert, G. Zeug, and E. Krausmann, Tsunami Vulnerability and Risk Analysis Applied to the City of Alexandria, Egypt. (Italy: European Commission, 2009)

13. Sumaryono. Assessing Building Vulnerability to Tsunami Hazard Using Integrative Remote Sensing and GIS Approaches. (München: LudwigMaximilians-Universität, 2010)

14. A. Atillah, D.E. Hadani, H. Moudni, O. Lesne, C. Renou, A. Mangin, and F. Rouffi, Tsunami vulnerability and damage assessment in the coastal area of Rabat and Sal'e, Morocco. Natural Hazards Earth System Sciences. 11, 3397-3414, (2011)
15. J.L. Barros, A. Emídio, A. Santos, and A.O. Tavares, Composite methodology for tsunami vulnerability assessment based on the numerical simulation of 1755 Lisbon tsunami-application on two Portuguese coastal areas. 'In: Safety and Reliability: Methodology and Applications. ed. by Nowakowski, T. et al. London: Taylor \& Francis Group: 1581, (2015)

16. I. Sivakumar, and R. Sivagamasundari, A Statistical Model for Assessing Building Vulnerability to Tsunami In Coastal Region'. Asian Journal of Civil Engineering (BHRC). 16 (4). 547-555, (2015)

17. Reinaldi. Mikrozonasi Gempa Maksimum dan Tingkat Kerentanan Terhadap Bahaya Gempa Di Kodya Semarang. (Maranatha University, Bandung, 2002)

18. I. Syabri, Kajian Resiko Kegempaan di Kotamadya Bandung. (ITB Department, Bandung, 1997)

19. N.N. Afatia, A. Deliar, R. Virtriana, Matrices scenario of pairwise comparison in risk analysis of pyroclastic flows of Semeru Volcano, East Java'. Jurnal Lingkungan dan Bencana Geologi, 3(3), 211 $-227,(2012)$

Table 1. Scenario 1: Pair wise comparison matrix and the criteria scores of hazard, vulnerability and capacity [19]

\begin{tabular}{lllll}
\hline Criteria & Hazard & Vulnerability & Capacity & Weight \\
\hline Hazard & $1 / 1$ & $1 / 1$ & $1 / 1$ & 0,3333 \\
\hline Vulnerability & $1 / 1$ & $1 / 1$ & $1 / 1$ & 0,3333 \\
\hline Capacity & $1 / 1$ & $1 / 1$ & $1 / 1$ & 0,3333 \\
\hline
\end{tabular}

Table 2. Scenario 2: Pair wise comparison matrix and the criteria scores of hazard, vulnerability and capacity [19]

\begin{tabular}{lllll}
\hline Criteria & Hazard & Vulnerability & Capacity & Weight \\
\hline Hazard & $1 / 1$ & $5 / 1$ & $9 / 1$ & 0,7231 \\
\hline Vulnerability & $1 / 5$ & $1 / 1$ & $5 / 1$ & 0,2157 \\
\hline Capacity & $1 / 9$ & $1 / 5$ & $1 / 1$ & 0,0612 \\
\hline
\end{tabular}

